\title{
Plankton metabolism and dissolved organic carbon use in the Bay of Palma, NW Mediterranean Sea
}

\author{
Nuria Navarro $^{1,2, *}$, Susana Agustí ${ }^{1}$, Carlos M. Duarte ${ }^{1}$ \\ ${ }^{1}$ IMEDEA (CSIC-UIB), Grupo de Oceanografía Interdisciplinar, Instituto Mediterráneo de Estudios Avanzados, \\ C/ Miquel Marqués 21, 07190 Esporles, Spain \\ ${ }^{2}$ Present address: Área de Biodiversidad y Conservación, ESCET, Universidad Rey Juan Carlos, \\ C/ Tulipán s/n, Móstoles 28933, Madrid, Spain
}

\begin{abstract}
A study was conducted to assess the annual variability in planktonic metabolism and dissolved organic carbon (DOC) utilization in an oligotrophic Mediterranean Bay (Bay of Palma, Spain) and to test the role of elevated DOC concentrations in driving planktonic metabolism off balance. We examined, at monthly intervals over 17 mo, gross primary production (GPP), community respiration $(\mathrm{R})$, net community production $(\mathrm{NCP})$, DOC concentration, total chlorophyll a (chl a) concentration, and, for a smaller subset of 11 to $14 \mathrm{mo}$, net DOC fluxes, bacterial abundance (BA) and bacterial respiration (BR). The community was net heterotrophic in autumn, winter and the first summer studied, and shifted to net autotrophic towards the end of the study period. This period of sustained autotrophy was an anomalous period characterized by frequent storms that stimulated autotrophic processes in the bay, leading to the development of a bloom of the cyanobacteria Synechoccocus. Use of DOC was consistent with the trophic state of the system, as DOC consumption was observed during periods when the system was net heterotrophic and there was a net DOC production when the system shifted to autotrophic. Bacterial respiration accounted for, on average, $51.76 \%$ of $\mathrm{R}$ and increased as the percent of cells with high DNA content increased. The planktonic community was net heterotrophic on an annual basis, suggesting that the system imports DOC. In particular, the organic carbon import may derive from the excess production of the underlying Posidonia oceanica meadow.
\end{abstract}

KEY WORDS: Net community production · Community respiration $\cdot$ Gross primary production $\cdot$ Net DOC production $\cdot$ Bacterial abundance $\cdot$ Bacterial respiration

Resale or republication not permitted without written consent of the publisher

\section{INTRODUCTION}

The role of planktonic communities in biogeochemical cycling can be summarized through the assessment of their metabolic balance, involving 2 primary, and opposed, physiological processes: gross primary production (GPP) and community respiration (R). The balance between these 2 processes is the net community production (NCP). Autotrophic communities, with positive NCP (i.e. GPP > R) are net sources of organic matter and oxygen, and sinks of $\mathrm{CO}_{2}$ and inorganic nutrients. The opposite applies to heterotrophic communities. NCP constrains, under steady-state conditions, the capacity of the plankton to export (E) or import (I) organic carbon as NCP $=\mathrm{E}$ or I $=\mathrm{GPP}-\mathrm{R}$,
(Rivkin \& Legendre 2001). Emphasis on primary production has led to the compilation of a thorough data set on GPP, whereas knowledge of the other 2 rate processes ( $\mathrm{R}$ and NCP) is quite poor (Williams 2000, del Giorgio \& Duarte 2002).

Whereas the metabolism of oceanic planktonic communities appears to be in approximate balance (GPP $\approx$ $R_{i}$ Williams 1998, but see Duarte \& Agustí 1998, Duarte et al. 1999, 2001, del Giorgio \& Duarte 2002), the allochthonous inputs of organic matter to coastal waters generate a potential for R to exceed GPP (Smith \& Hollibaugh 1996). Indeed, the dissolved organic carbon (DOC) concentration of coastal waters is generally elevated (coastal DOC $>90 \mu \mathrm{M}$ ) relative to the DOC concentration in surface waters of the open ocean 
( 63 $\mu \mathrm{M}$, cf. Arístegui et al. 2002). The elevated DOC concentration of coastal waters may be a product of allochthonous inputs, from rivers (e.g. Meybeck 1982) or benthic release (Brylinsky 1977, Ziegler \& Benner 1999, Eyre \& Ferguson 2002), or may derive from release by planktonic autotrophs (Choi 1972, Nagata \& Kirchman 1992, Morán et al. 2002). An autochthonous source appears unlikely in most cases, as pelagic coastal waters have been claimed to be, in general, heterotrophic (Smith \& Hollibaugh 1997), e.g. as observed in Mediterranean coastal waters (Satta et al. 1996). The elevated DOC sources in coastal waters provide a potential supply of additional bioavailable compounds that potentially support respiration in coastal waters. Bacteria may, in these situations, provide an entry point for allochthonous DOC to planktonic coastal food webs, as they are the most important consumers of DOC as well being the major contributors to pelagic respiration, especially in oligotrophic waters (del Giorgio \& Duarte 2002). Yet, research has traditionally focused on particulate carbon flux and there is still limited knowledge of the dynamics of DOC over seasonal scales (Morán et al. 2002).

Here, we assess the annual variability in planktonic metabolism and DOC utilization in an oligotrophic Mediterranean Bay (Bay of Palma, Mallorca, Spain) to test the postulated role of elevated DOC concentrations in driving planktonic metabolism off balance. We examine, at monthly intervals over $17 \mathrm{mo}$, planktonic GPP, R and NCP, DOC concentration, chlorophyll a (chl a) concentration and, for a smaller subset of 11 to $14 \mathrm{mo}$, net DOC fluxes, and BA and BR.

\section{MATERIALS AND METHODS}

The study was conducted in the Bay of Palma (Mallorca, Spain), a large (mean depth $31 \mathrm{~m}, 19.3 \mathrm{~km}$ across, $215.8 \mathrm{~km}^{2}$ ) oligotrophic bay (Fig. 1). The bay contains an important population, with a resident population of about 400000 persons concentrated in the city of Palma de Mallorca ( 360000 inhabitants) and a seasonal maximum population of approximately 500000 inhabitants in summer, at full occupation of the tourist resorts throughout the bay. The bay has a residence time of about 9 to 13 d, depending, on wind conditions (Werner et al. 1993), and therefore maintains oligotrophic conditions despite sporadic inputs from urban runoff during storm surges (Jansá 1994).
Sampling was conducted at a station $\left(39^{\circ} 30.233^{\prime} \mathrm{N}\right.$, $2^{\circ} 32.600^{\prime}$ E) overlying a Posidonia oceanica meadow at $8 \mathrm{~m}$ depth. The water column at this station was vertically mixed throughout the study, as evidenced by CTD profiles conducted at monthly intervals, including a PAR sensor. Integrated ( 0 to $7 \mathrm{~m}$ ) water samples were collected with a vertical $7 \mathrm{~m}$ long tube to deliver the contents into acid-washed carboys. The carboys were well mixed before collecting subsamples for planktonic metabolism, DOC use, chl a concentration and heterotrophic bacteria abundance. Sampling was conducted monthly from June 2001 to October 2002.

Water samples for community metabolism were carefully siphoned into nineteen $125 \mathrm{ml}$ narrow-mouth Winkler bottles. Five replicates were used to determine the initial oxygen concentration and 7 replicate bottles were used for incubation in the 'dark' and in the 'light'. The bottles for 'light' (transparent) and 'dark' (opaque) incubations were suspended in situ at a depth of $4 \mathrm{~m}$ and incubated for $24 \mathrm{~h}$. R, GPP and NCP rates are properties related by the mass balance equation: NCP $=$ GPP - R. Operationally, this mass balance equation is derived from changes in oxygen concentrations in the incubated bottles relative to the initial concentration. R and NCP were calculated from changes in dissolved oxygen concentration after incubation of

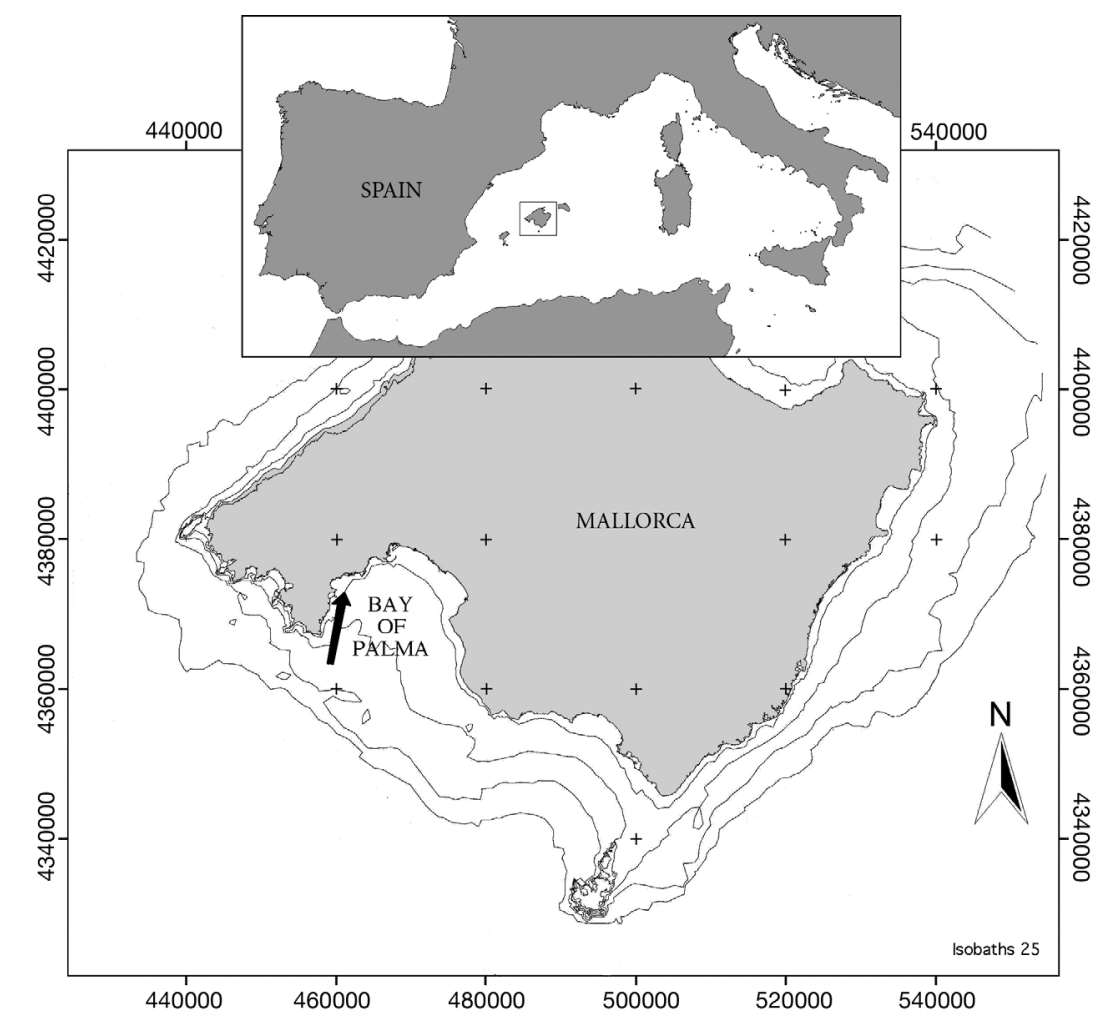

Fig. 1. Map of the study area, the Bay of Palma, Mallorca. Arrow points to sampling station 
samples under 'dark' and 'light' conditions, respectively. GPP was calculated as the sum of R and NCP. Ten replicate 'dark' bottles for BR were filled with filtered water (Whatman GF/F, low vacuum pressure) and incubated at in situ temperature. Five replicates were used to determine the initial oxygen concentration and 5 replicates were incubated. Enclosure of microbial communities may affect the structure of the community (Massana et al. 2001). However, there is evidence that respiration rates are maintained despite these changes (Pomeroy et al. 1994).

The dissolved oxygen was fixed immediately upon retrieval and measured by the Winkler technique, following the recommendations of Carritt \& Carpenter (1966), by means of an automated precise titration system (Mettler DL21 Auto-titrator) with potentiometric (redox electrode) end-point detection (Oudot et al. 1988). The average precision achieved in replicates was $\% \mathrm{CV}=0.29$. Examination of vertical profiles of gross primary production conducted in March and June 2002 (J. P. Gattuso unpubl. data) showed no evidence of differences in GPP across the $8 \mathrm{~m}$ water column depth, which remained above the saturating irradiance.

The seasonal evolution of the trophic conditions were characterized by the GPP/R ratio, where GPP/R > 1 represents net autotrophy, GPP/R $=1$ is metabolic balance and GPP/R $<1$ is net heterotrophy.

Annual NCP and GPP, and R and BR measured as change in $\mathrm{O}_{2}$ concentration $\left(\mu \mathrm{mol} \mathrm{O}_{2} \mathrm{dm}^{-3} \mathrm{~d}^{-1}\right.$ ) were transformed into organic $\mathrm{C}$ production and losses, respectively. We used an average photosynthetic quotient ( $\mathrm{PQ} ;$ mol of $\mathrm{O}_{2}$ produced per mol of $\mathrm{CO}_{2}$ fixed) and a respiratory quotient $\left(\mathrm{RQ}_{\mathrm{i}} \mathrm{mol}\right.$ of $\mathrm{CO}_{2}$ produced per mol of $\mathrm{O}_{2}$ consumed) of 1 (Williams et al. 1979). Results were expressed in $\mathrm{g} \mathrm{C} \mathrm{m}^{-3} \mathrm{yr}^{-1}$.

Net DOC production or use by the planktonic community was calculated from changes in DOC concentrations after in situ incubation of samples in 'light' Winkler bottles over $24 \mathrm{~h}$. Five replicates were used to determine the initial and final DOC concentrations. Samples for DOC analysis $(10 \mathrm{ml})$ were immediately filtered through a pre-combusted $\left(450^{\circ} \mathrm{C}\right.$ for a minimum of $4 \mathrm{~h}$ ) GF/F filter and collected in acidwashed glass ampoules. Samples were preserved by adding $100 \mu \mathrm{l}$ of $2 \mathrm{~N} \mathrm{HCl}$ before flame-sealing the ampoules. The DOC analysis was performed using Pt-catalyzed high temperature combustion on a Shimadzu TOC-5000A analyzer (Benner \& Strom 1993). Distilled UV-radiated water from a Millipore Symplicity ultrapure water system was used to prepare blanks, and standard curves were prepared with potassium biphthalate (range: 0 to $400 \mu \mathrm{mol} \mathrm{C}{ }^{-1}$ ). The instrument blank was assessed using 2 external standards ( 44 to 45 and $2 \mu \mathrm{M}$ ) provided by Dennis A.
Hansell and Wenhao Chen (University of Miami). The instrument blank ranged between 0.5 and $5.2 \mu \mathrm{mol} \mathrm{C}{ }^{-1}$ and was subtracted from the measurements.

Samples of $200 \mathrm{ml}$ were filtered through Whatman GF/F filters to estimate total chl a concentration. Chl a was measured fluorometrically (Turner Designs fluorometer) in $90 \%$ acetone extracts of filters preserved frozen following the procedures of Parsons et al. (1984).

Samples of $1.5 \mathrm{ml}$ for bacteria counts were fixed with $1 \%$ paraformaldehyde $+0.05 \%$ glutaraldehyde (final), incubated for $10 \mathrm{~min}$ in the dark, deep-frozen in liquid nitrogen and then stored frozen at $-70^{\circ} \mathrm{C}$. Bacterial samples were later thawed, stained with Syto13 (Molecular Probes) at $5 \mu \mathrm{M}$ (diluted in DMS) in the dark for 10 min and run through a flow cytometer (Becton Dickinson FACSCalibur 3CS bench cytometer with a laser emitting at $488 \mathrm{~nm}$ ). Samples were run at low speed and data were acquired in log mode until around 10000 events were acquired. Polysciences latex beads of yellow-green $0.92 \mu \mathrm{m}$ were added as an internal standard $\left(10 \mu \mathrm{l}\right.$ per $400 \mu \mathrm{l}$ sample of a $1.5 \times 10^{6} \mathrm{ml}^{-1}$ beads solution). Bacteria were detected by their signature in a plot of side light scatter (SSC) versus green fluorescence (FL1). Bacteria with apparent high DNA (HDNA) content were separated from bacteria with apparent low DNA (LDNA) content in the SSC versus FL1 plot. The relative abundance of HDNA and LDNA bacteria provides a rough indication of the 'actively metabolizing' versus the 'less actively metabolizing' bacteria in the community (Gasol et al. 1999). When instrument and particle noise interfered with the SSC versus FL1 signals of LDNA bacteria, the bacterial populations were separated from noise by using FL1 versus red fluorescence (FL3) plots. In such plots, the bacterial cells, both HDNA and LDNA, remain in a diagonal line, while the beads are placed in a parallel diagonal, both separated from noise signal (Gasol et al. 1999).

\section{RESULTS}

Seawater temperature ranged between $13.92^{\circ} \mathrm{C}$ in January 2002 and $27.20^{\circ} \mathrm{C}$ in August 2001 (Fig. 2). CTD profiles showed that the $8 \mathrm{~m}$ water column of the station remained well mixed throughout the study and that the waters remained clear throughout most of the study (extinction coefficient generally $<0.03 \mathrm{~m}^{-1}$, average $=0.06 \pm 0.02 \mathrm{~m}^{-1}$ ), with an average of $79 \%$ of the surface irradiance incident at $4 \mathrm{~m}$ depth and $72 \%$ at the bottom.

GPP rates ranged from 0.14 to $14.02 \mu \mathrm{mol} \mathrm{O}_{2} \mathrm{dm}^{-3}$ $\mathrm{d}^{-1}$ (Fig. 2), with a considerable contrast between GPP 

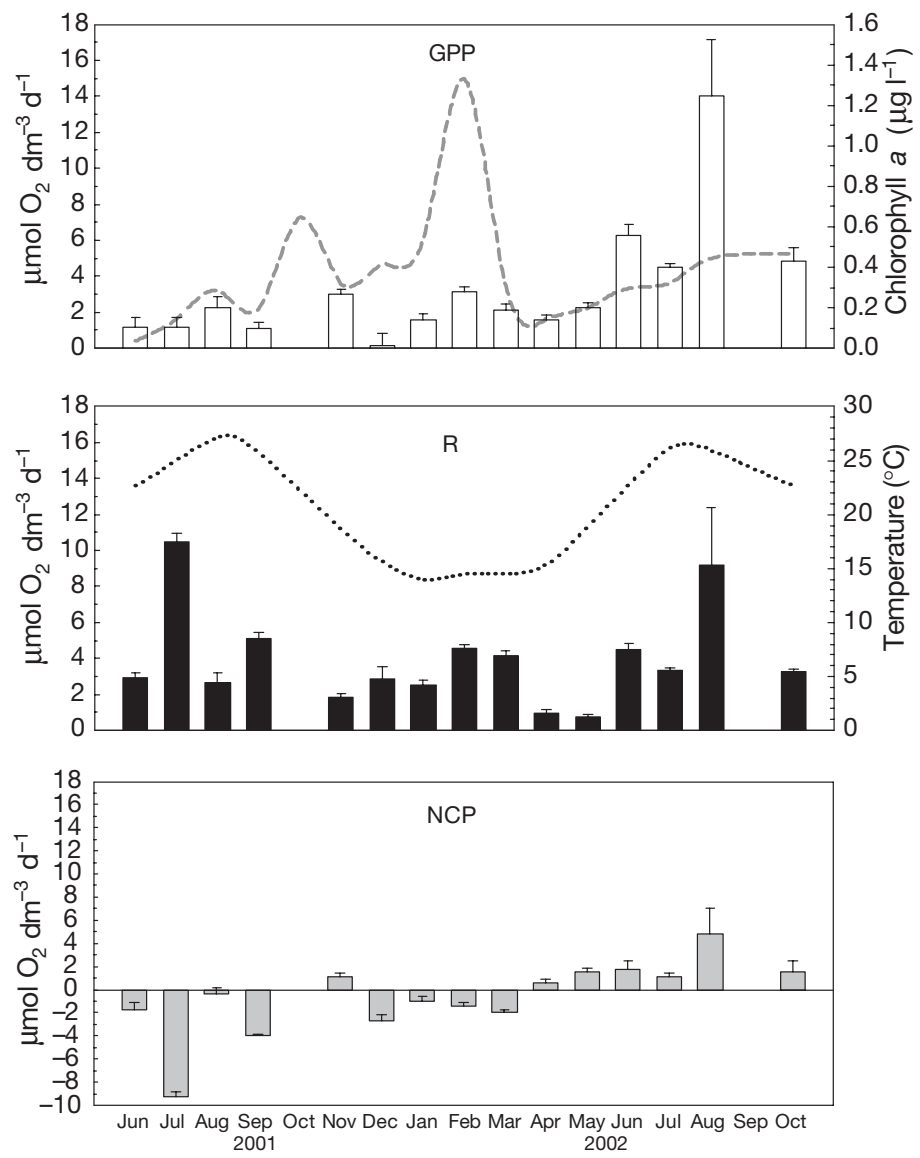

Fig. 2. Gross primary production (GPP), community respiration $(\mathrm{R})$, net community production (NCP), total chlorophyll a concentration (---) and seawater temperature (…) during the study period. Error bars are $\pm \mathrm{SE}$

values in summer 2001 relative to those of 2002, when very high values were reached in August, corresponding with a bloom of the cyanobacteria Synechococcus (P. Alonso unpubl. data). GPP was lower in winter, except for relatively high values in February, coinciding with the late winter phytoplankton bloom, when maximal chl a concentrations of $1.33 \mu \mathrm{g} \mathrm{l}^{-1}$ were observed (Fig. 2). There was a tendency for GPP to increase with chl a (Fig. 3a) at higher rates during the autotrophic period (regression slope $=24.32 \pm$ $11.75, \mathrm{r}^{2}=0.46, \mathrm{p}<0.05$ ) of the community (Fig. 4) than during the heterotrophic period (regression slope $\left.=1.43 \pm 0.71, r^{2}=0.40, p<0.05\right)$. GPP was statistically independent of water temperature $\left(r^{2}=0.14\right.$, $\mathrm{p}>0.16)$.

$\mathrm{R}$ rates ranged from 0.72 to $10.45 \mu \mathrm{mol} \mathrm{O}_{2} \mathrm{dm}^{-3} \mathrm{~d}^{-1}$ (Fig. 2), with high respiration rates in summer and reduced rates $\left(<1 \mu \mathrm{mol} \mathrm{O}_{2} \mathrm{dm}^{-3} \mathrm{~d}^{-1}\right)$ during spring and autumn. $\mathrm{R}$ tended to increase with increasing water temperature $\left(\mathrm{r}^{2}=0.61, \mathrm{p}<0.05\right)$ and with chl a concentrations (Fig. 3b), although only during the autotrophic period of the community $\left(r^{2}=0.49, p<\right.$ 0.05).

BA ranged from $2.07 \times 10^{5}$ cells ml ${ }^{-1}$ in January to $1.52 \times 10^{6}$ cells ml $^{-1}$ in July (Fig. 5a). The percentage of HDNA bacteria or actively metabolizing bacteria (\% HDNA in BA) ranged from $41.15 \%$ in November to $85.50 \%$ in June (Fig. 5a). BR ranged from 0.27 to $3.64 \mu \mathrm{mol} \mathrm{O} \mathrm{dm}^{-3} \mathrm{~d}^{-1}$ (Fig. 5b), with maximum values observed in February and June, and minimum values in May. BR increased with an increasing percentage of HDNA bacteria $\left(\mathrm{r}^{2}=0.65, \mathrm{p}<0.05\right.$; Fig. 5c). BR accounted for on average $51.76 \%$ of community respiration, ranging from 25.54 to $97.09 \%$ (Table 1, Fig. 5b).

NCP rates ranged from -9.28 to $4.84 \mu \mathrm{mol} \mathrm{O}_{2} \mathrm{dm}^{-3}$ $\mathrm{d}^{-1}$ (Fig. 2). The community was net heterotrophic in autumn, winter and summer but shifted to net autotrophic in spring and summer 2002 (Fig. 4). NCP rates tended to decrease as $\mathrm{R}$ rates increased, except for August 2002, when NCP was high despite high R (Fig. 6a) and NCP rates tended to increase nonlinearly with increasing GPP $\left(\mathrm{r}^{2}=0.52, \mathrm{p}<0.05\right.$, Fig. 6b). The average GPP/R ratio was $0.83 \pm 0.33$, indicative of a prevalence of heterotrophic communi-
Fig. 3. (a) Relationship between gross primary production (GPP) and total chlorophyll a (chl a) concentration, and (b) between community respiration (R) and chl a during the autotrophic and heterotrophic periods of the community. The solid line represents the fitted regression equation of the autotrophic period. The dotted line represents the fitted regression equation of the heterotrophic period. Error bars are \pm SE
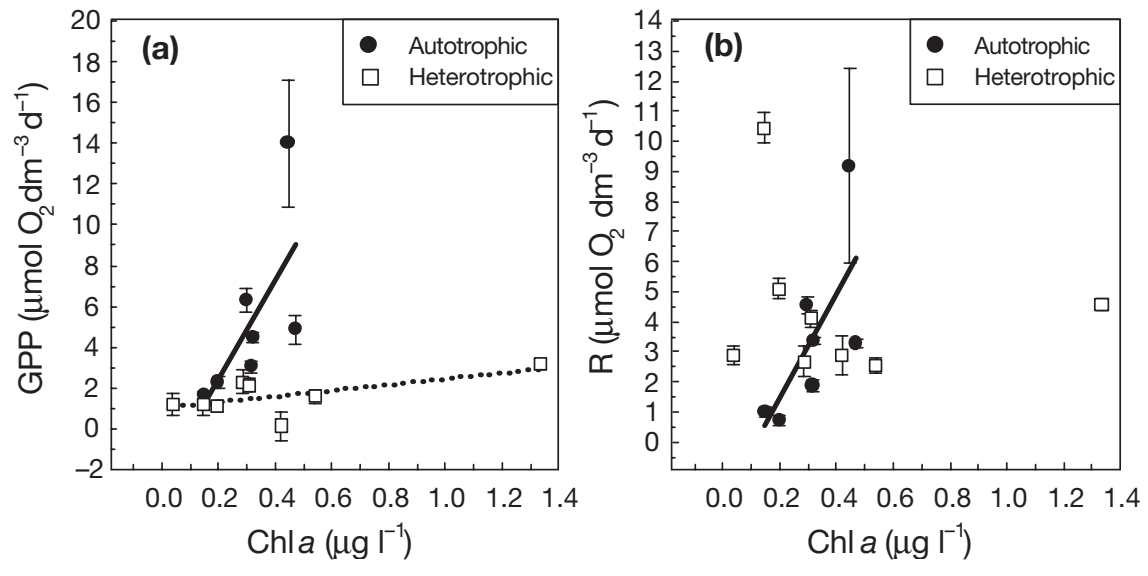
ties (GPP/R $<1)$. The GPP/R ratio tended to increase during the study period $\left(\mathrm{r}^{2}=0.36\right.$, $\mathrm{p}<0.05$, Fig. 4). The average GPP during the study period corresponds to $14.39 \pm$ $2.67 \mathrm{~g} \mathrm{C} \mathrm{m}^{-3} \mathrm{yr}^{-1}$ whereas the community respired $17.27 \pm 2.14 \mathrm{~g} \mathrm{C} \mathrm{m}^{-3} \mathrm{yr}^{-1}$, of which $6.64 \pm 1.13 \mathrm{~g} \mathrm{C} \mathrm{m}^{-3} \mathrm{yr}^{-1}$ can be assigned to $\mathrm{BR}$, implying that the community tended to be heterotrophic, with an organic carbon deficit of $2.88 \pm 2.43 \mathrm{~g} \mathrm{C} \mathrm{m}^{-3} \mathrm{yr}^{-1}$ (Table 1).

DOC concentration averaged 103.26 \pm $4.87 \mu \mathrm{mol} \mathrm{C} \mathrm{dm}{ }^{-3}$ and ranged from 85.35 to $135.43 \mu \mathrm{mol} \mathrm{C} \mathrm{dm}{ }^{-3}$ with 2 maxima, in October and August (Fig. 7a). DOC concentration increased with increasing temperature $\left(\mathrm{r}^{2}=\right.$ $0.60, \mathrm{p}<0.01$ ), with DOC accumulating over the summer. Net DOC consumption averaged $-5.50 \pm 2.56 \mu \mathrm{mol} \mathrm{C} \mathrm{dm}{ }^{-3} \mathrm{~d}^{-1}$ and net DOC production averaged $4.99 \pm 1.74 \mu \mathrm{mol}$

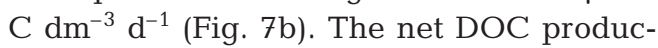
tion was consistent with the trophic state of the system, as net DOC consumption was observed when the system was net heterotrophic $\left(-3.24 \pm 3.55 \mu \mathrm{mol} \mathrm{C} \mathrm{dm}{ }^{-3} \mathrm{~d}^{-1}\right)$ and net DOC production was observed when the system shifted to autotrophic $(2.72 \pm$

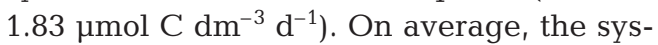
tem consumed DOC at an average annual rate of $1.13 \pm 9.45 \mathrm{~g} \mathrm{C} \mathrm{m}^{-3} \mathrm{yr}^{-1}$, accounting for about $50 \%$ of the excess heterotrophy (Table 1).

\section{DISCUSSION}

The planktonic metabolism in the Bay of Palma tended to be heterotrophic on an annual scale, as reported elsewhere for the NW Mediterranean littoral (Satta et al. 1996), although by such a small margin that it did not statistically depart from metabolic balance. Pulses of intense metabolism may occur at frequencies that would not be captured by monthly samples (cf. Karl et al. 2003), so that the annual estimates derived here could be somewhat different should more intense sampling be conducted. Yet, a high-frequency sampling (weekly for $7 \mathrm{yr}$ ) programme conducted in another Mediterranean bay failed to provide evidence for such bursts of autotrophy (Duarte et al. 2004), so they may not occur in the Bay of Palma either. When examined at seasonal time scales, the system studied shifted from periods of heterotrophy to

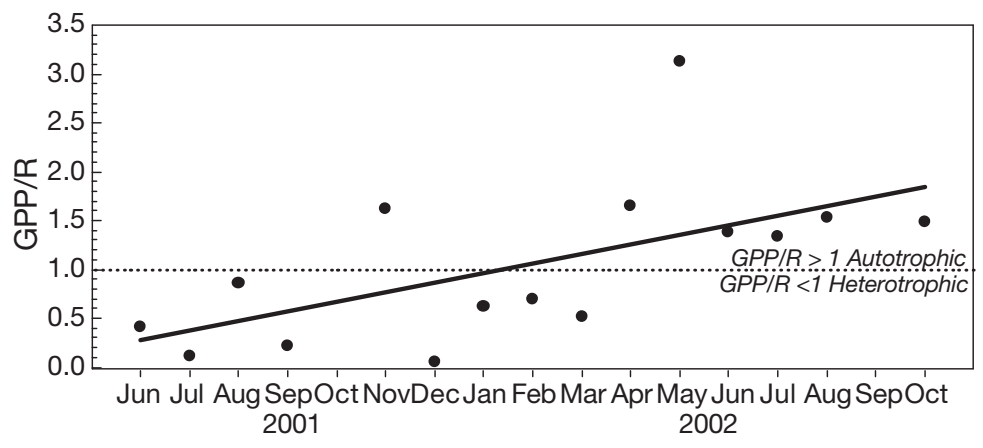

Fig. 4. The quotient GPP/R during the study period. The solid line represents the fitted regression equation
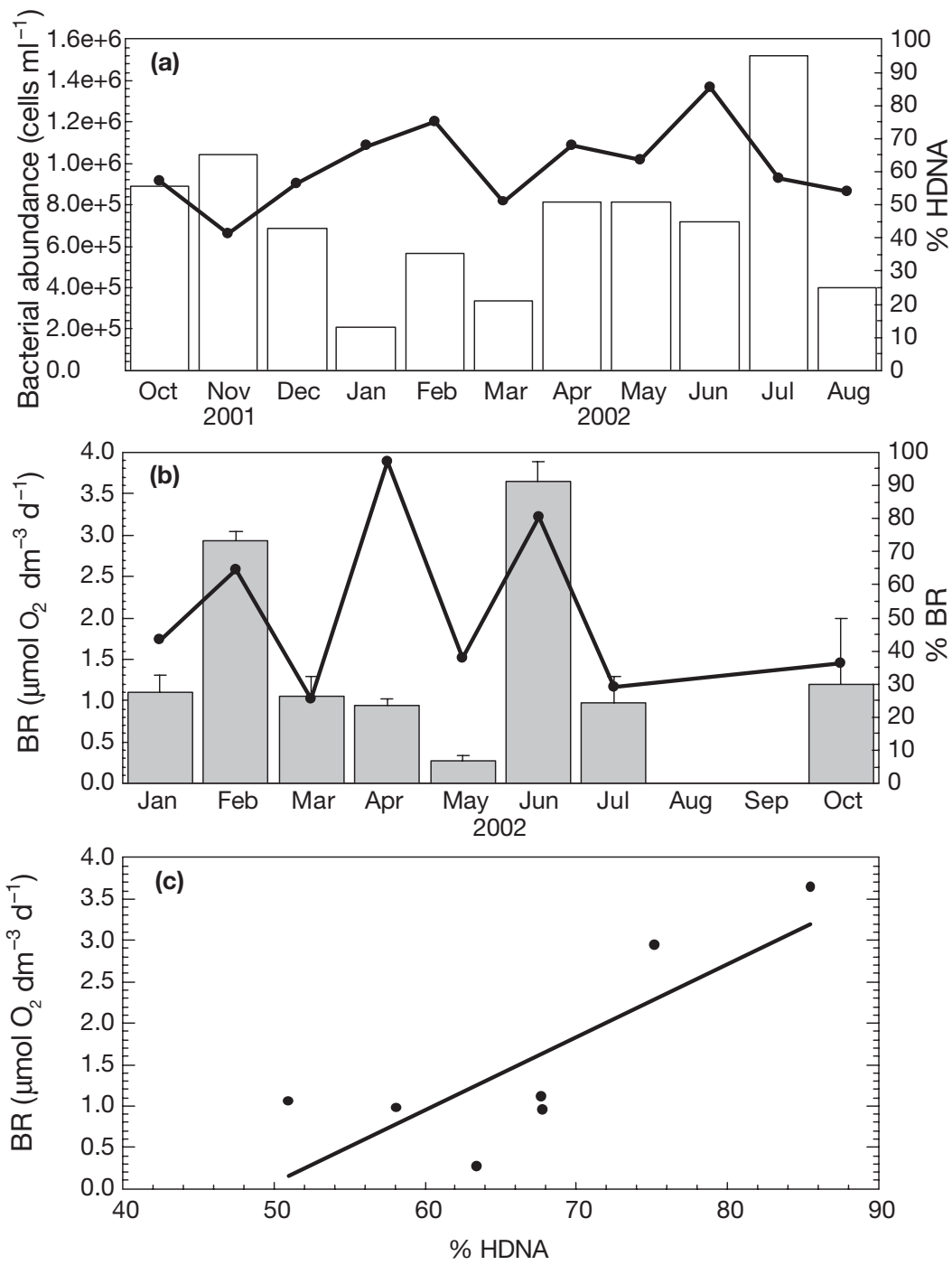

Fig. 5. (a) Bacterial abundance (columns) and \% high DNA bacteria (\%HDNA, line) during the study period. (b) Bacterial respiration (BR, columns) and \% bacterial respiration in total $\mathrm{R}$ ( $\% \mathrm{BR}$, line) during the study period. Error bars are \pm SE. (c) Relationship between BR and \%HDNA bacteria. The solid line represents the fitted regression equation 
Table 1. Annual average (Avg), SE, minimum (Min.) and maximum (Max.) values of gross primary production (GPP), community respiration (R), net community production (NCP), bacterial respiration (BR), \% bacterial respiration in total $\mathrm{R}$ $(\% \mathrm{BR})$ and net DOC production (Net DOC). Annual average corresponds to the average of a moving window of $12 \mathrm{mo}$ sliding along the study period

\begin{tabular}{|lrrrr|}
\hline & Avg & SE & Min. & Max. \\
\hline GPP $\left(\mathrm{g} \mathrm{C} \mathrm{m}^{-3} \mathrm{yr}^{-1}\right)$ & 14.39 & 2.67 & 7.82 & 17.32 \\
$\mathrm{R}\left(\mathrm{g} \mathrm{C} \mathrm{m}^{-3} \mathrm{yr}^{-1}\right)$ & 17.27 & 2.14 & 13.27 & 16.10 \\
$\mathrm{NCP}\left(\mathrm{g} \mathrm{C} \mathrm{m}^{-3} \mathrm{yr}^{-1}\right)$ & -2.88 & 2.43 & -7.63 & -0.03 \\
$\mathrm{BR}\left(\mathrm{g} \mathrm{C} \mathrm{m}^{-3} \mathrm{yr}^{-1}\right)$ & 6.64 & 1.13 & 1.20 & 15.96 \\
\%BR & 51.76 & 9.21 & 25.54 & 97.09 \\
Net DOC $\left(\mathrm{g} \mathrm{C} \mathrm{m}^{-3} \mathrm{yr}^{-1}\right)$ & -1.13 & 9.45 & -10.68 & 2.42 \\
\hline
\end{tabular}

periods of autotrophy, which do not seem to correspond to a simple seasonal pattern. Community heterotrophy prevailed at GPP rates $<3 \mu \mathrm{mol} \mathrm{O}_{2}$ $\mathrm{dm}^{-3} \mathrm{~d}^{-1}$. The threshold of $3 \mu \mathrm{mol} \mathrm{O} \mathrm{O}_{2} \mathrm{dm}^{-3} \mathrm{~d}^{-1}(0.09 \mathrm{~g}$ $\mathrm{O}_{2} \mathrm{~m}^{-3} \mathrm{~d}^{-1}$ ) separating autotrophic from heterotrophic communities is very close to the threshold of $0.12 \mathrm{~g}$ $\mathrm{O}_{2} \mathrm{~m}^{-3} \mathrm{~d}^{-1}$ recently reported for another Mediterranean bay (Duarte et al. 2004). During the heterotrophic period of the system, there was a lack of cor-

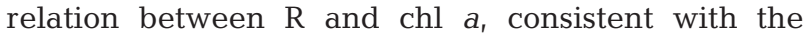
observation that bacteria were responsible for most of the respiration in the water column (Sherr \& Sherr 1996, Rivkin \& Legendre 2001). However, during the autotrophic period of the system, planktonic respiration tended to vary positively with chl a concentrations, suggesting that bacteria respond to increasing phytoplankton production and release of dissolved organic substrates (Biddanda et al. 2001). Several
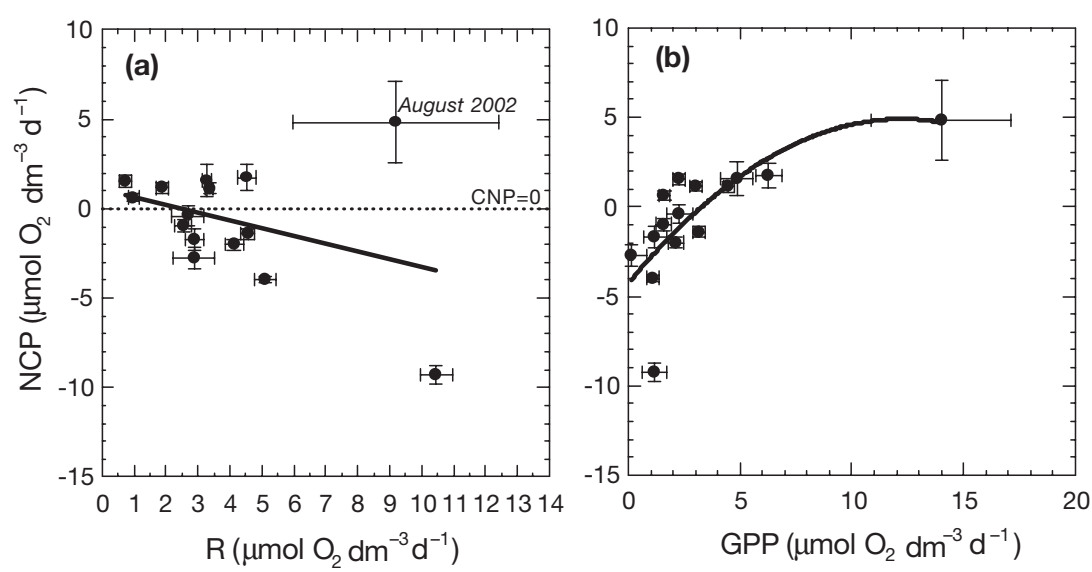

Fig. 6. (a) Relationship between net community production (NCP) and community respiration (R). (b) Relationship between NCP and gross primary production (GPP). The solid line represents the fitted regression equation. Error bars are $\pm \mathrm{SE}$ studies have documented that the contribution of bacteria to plankton respiration is large in oligotrophic waters but relatively small in eutrophic waters (del Giorgio et al. 1997, Biddanda et al. 2001). Indeed, bacterial respiration represented a large proportion (mean of $52 \%$ ) of community respiration, consistent with previous reports ( 50 to $>90 \%$; Sherr \& Sherr 1996, Biddanda \& Cotner 2002).

These results suggest that DOC production and subsequent use must be an important component of planktonic metabolism in the Bay of Palma. DOC accumulated from winter to late summer, with a range in DOC concentration from the annual minimum to the annual maximum of $50 \mu \mathrm{M}$ (Fig. 7a). However, this increase cannot be a local phenomenon, as the residence time of the bay is in the order of $10 \mathrm{~d}$, so that seasonal storage of DOC in the water column is not possible. It must instead reflect an accumulation in the coastal waters around the island of Mallorca or else derive from changing inputs, such as those possibly derived from the seagrass meadow that covers $36 \%$ of the benthic compartment of the Bay of Palma. Indeed, Ziegler \& Benner (1999) documented high release rates of DOC from seagrass beds in Laguna Madre, Texas, USA. The increase in DOC concentration with increasing temperature may be attributable to the increased organic matter released by phytoplankton cell lysis in summer, which is an important process in the Mediterranean littoral (Agustí \& Duarte 2000), as well as increased DOC release from benthic communities, particularly from the seagrass beds that cover a significant fraction of the Bay of Palma (Eyre \& Ferguson 2002). The 2 DOC maxima in October and August matched a chl a maxima and a large Synechococcus bloom, respectively, and these agree with Carlson et al. (1994), who reported increased DOC stocks during phytoplankton blooms.

DOC was consumed during heterotrophic phases of the system whereas DOC was released during autotrophic ones (Fig. 7b), further suggesting an important role of DOC in the metabolism of the Bay of Palma. Overall, the planktonic community was heterotrophic with the extent of heterotrophy closely matching the average net DOC consumption.

On an annual basis, the planktonic community in the Bay of Palma tended to be net heterotrophic, suggesting that the system imports organic carbon, mostly as DOC, either derived from land (storm runoff) or released by benthic communities. In particular, the organic carbon import may come from the excess 

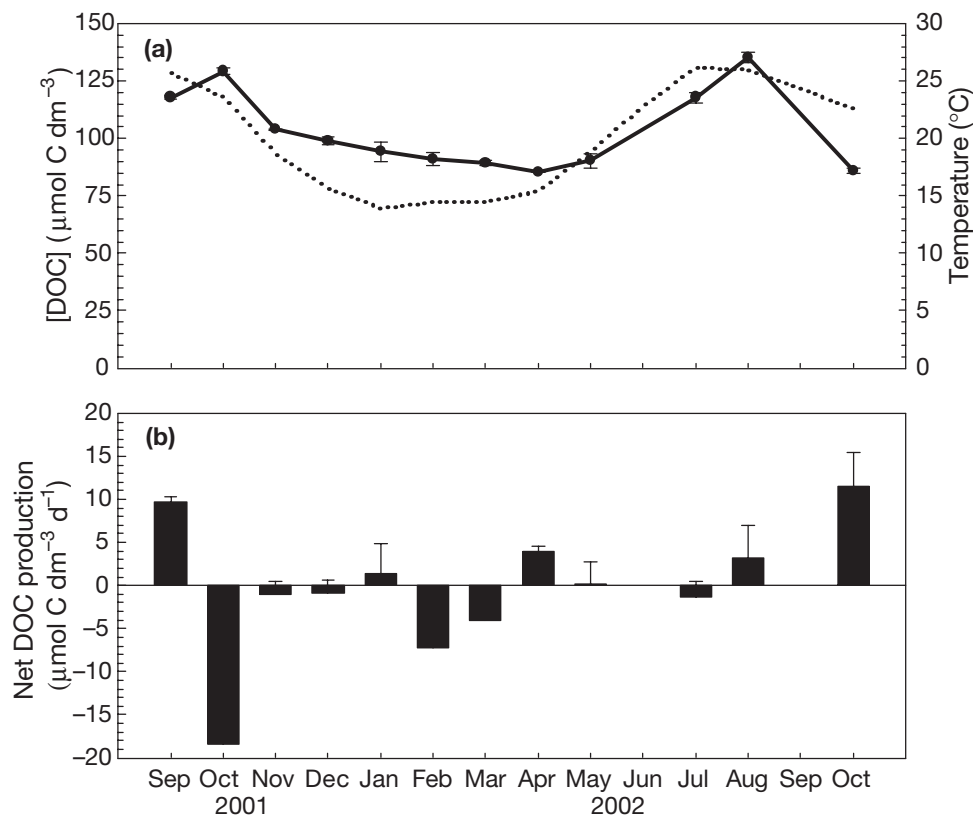

Fig. 7. (a) Dissolved organic carbon (DOC) concentration (-) and seawater temperature (.....) during the study period. (b) Net DOC production during the study period. Negative net DOC production indicates net consumption. Error bars are $\pm \mathrm{SE}$

production of the Posidonia oceanica meadow of the Bay of Palma (C. Barrón unpubl. results). However, the community shifted from a prevalence of heterotrophy during the initial phase of the study to autotrophic over the second half of the study. Indeed, the periods of sustained autotrophy in the summer of 2002 corresponded with an anomalous summer, characterized by frequent and severe storms when the highest rainfall on record for this period was reached (rainfall in summer 2002 was 12-fold higher than that in summer 2001), generating an excess runoff to the Bay of Palma at a time when nutrient concentrations are otherwise low. Dissolved phosphorus increased by $68 \%$ and total dissolved nitrogen increased by $32 \%$ in June and July 2002. This anomaly stimulated autotrophic processes in the bay, leading to the development of a large bloom of Synechoccocus. Hence, whereas heterotrophy prevailed in the metabolism of the planktonic community of the Bay of Palma, consistent with results from other Mediterranean littoral waters (Satta et al. 1996), increased nutrient inputs such as those derived from the anomalous conditions experienced in the summer of 2002 may lead to autotrophy. These results, therefore, support the notions that unproductive planktonic communities tend to be net heterotrophic and that DOC plays an important role as a substrate to support the excess respiration.
Acknowledgements. This research is part of the project 'Nutrients Cycling and the Trophic Status of Coastal Ecosystems' (EUROTROPH, contract EVK3-CT-200000040 of the European Commission) and was co-funded by the Spanish National Plan of I+D. We thank R. Santiago, C. Barrón, N. Cantero, R. Martinez and S. Ruiz for invaluable assistance in the field and laboratory. N.N. was supported by a grant from the Spanish Ministry of Education.

\section{LITERATURE CITED}

Agustí S, Duarte CM (2000) Strong seasonality in phytoplankton cell lysis in the NW Mediterranean littoral. Limnol Oceanogr 45(4):940-947

Arístegui J, Duarte CM, Agustí S, Doval M, Álvarez-Salgado XA, Hansell DA (2002) Dissolved organic carbon support of respiration in the dark ocean. Science 298:1967

Benner R, Strom M (1993) A critical evaluation of the analytical blank associated with DOC measurements by hightemperature catalytic oxidation. Mar Chem 41:153-160

Biddanda BA, Cotner JB (2002) Love handles in aquatic ecosystems: the role of dissolved organic carbon drawdown, resuspended sediments, and terrigenous inputs in the carbon balance of Lake Michigan. Ecosystems 5: 431-445

Biddanda BA, Ogdahl M, Cotner JB (2001) Dominance of bacterial metabolism in oligotrophic relative to eutrophic waters. Limnol Oceanogr 46:730-739

Brylinsky M (1977) Release of dissolved organic matter by some marine macrophytes. Mar Biol 39:213-220

Carlson CA, Ducklow HW, Michaels AF (1994) Annual flux of dissolved organic carbon from the euphotic zone in the northwestern Sargasso Sea. Nature 371:405-408

Carritt DE, Carpenter JH (1966) Comparison and evaluation of currently employed modifications of the Winkler method for determining dissolved oxygen in seawater; a NASCO Report. J Mar Res 24:286-319

Choi CI (1972) Primary production and release of dissolved organic carbon from phytoplankton in the western North Atlantic Ocean. Deep-Sea Res 19:731-735

del Giorgio P, Duarte CM (2002) Respiration in the open ocean. Nature 420:379-384

del Giorgio P, Cole JJ, Cimbleris A (1997) Respiration rates in bacteria exceed phytoplankton production in unproductive aquatic systems. Nature 385:148-151

Duarte CM, Agustí S (1998) The $\mathrm{CO}_{2}$ balance of unproductive aquatic ecosystems. Science 281:234-236

Duarte CM, Agustí S, del Giorgio P, Cole JJ (1999) Regional carbon imbalances in the oceans. Science 284:17-35

Duarte CM, Agustí S, Arístegui J, González N, Anadón R (2001) Evidence for a heterotrophic subtropical northeast Atlantic. Limnol Oceanogr 46:425-428

Duarte, CM, Agustí S, Vaqué D (2004) Controls on planktonic metabolism in the Bay of Blanes, north-western Mediterranean littoral. Limnol Oceanogr 49:2162-2170

Eyre BD, Ferguson AJP (2002) Comparison of carbon production and decomposition, benthic nutrient fluxes and denitrification in seagrass, phytoplankton, benthic microalgaeand macroalgae-dominated warm-temperate Australian lagoons. Mar Ecol Prog Ser 229:43-59

Gasol JM, Zweifel UL, Peters F, Fuhrman JA, Hagström Å (1999) Significance of size and nucleic acid content heterogeneity as measured by flow cytometry in natural planktonic bacteria. Appl Environ Microbiol 65: 4475-4483 
Jansá J, Fernández de Puelles ML, López-Jurado JL, Amengual R, Reñones O, Morillas A (1994) Variación anual e interanual de los factores fisicoquímico-biológicos generales del medio pelágico de la Bahía de Palma (Islas Baleares, España) desde Mayo de 1988 hasta Mayo de 1992. Inf Téc Inst Español Oceanogr 152

Karl DM, Laws EA, Morris P, Williams PJLeB, Emerson S (2003) Metabolic balance of the open sea. Nature 426:32

Massana R, Pedrós-Alió C, Casamayor EO, Gasol JM (2001). Changes in marine bacterioplankton phylogenetic composition during incubations designed to measure biogeochemically significant parameters. Limnol Oceanogr 46(5): $1181-1188$

Meybeck M (1982) Carbon, nitrogen and phosphorus transport by world rivers. Am J Sci 282:401-450

Morán XAG, Gasol JM, Pedrós-Alió C, Estrada M (2002) Partitioning of phytoplanktonic organic carbon production and bacterial production along a coastal-offshore gradient in the NE Atlantic during different hydrographic regimes. Aquat Microb Ecol 29:239-252

Nagata R, Kirchman DL (1992) Release of dissolved organic matter by heterotrophic protozoa: implications for microbial food webs. Arch Hydrobiol Beih Ergebn Limnol 35: 99-109

Oudot C, Gerard R, Morin P, Gningue I (1988) Precise shipboard determination of dissolved oxygen (Winkler procedure) for productivity studies with a commercial system. Limnol Oceanogr 33:146-150

Parsons TR, Maita Y, Lalli CM (1984) A manual of chemical and biological methods for seawater analysis. Pergamon Press, Oxford

Pomeroy LR, Sheldon JE, Sheldon WM (1994) Changes in bacterial numbers and leucine assimilation during estimations of microbial respiratory rates in seawater by precision Winkler method. Appl Environ Microbiol 60:328-332

Editorial responsibility: Fereidoun Rassoulzadegan, Villefranche-sur-Mer, France
Rivkin RB, Legendre L (2001) Biogenic carbon cycling in the upper ocean: effects of microbial respiration. Science 291: 2398-2400

Satta MP, Agustí S, Mura MP, Vaque D, Duarte CM (1996) Microplankton respiration and net community metabolism in a bay on the NW Mediterranean coast. Aquat Microb Ecol 10:165-172

Sherr EB, Sherr BF (1996) Temporal offset in the oceanic production and respiration processes implied by seasonal changes in atmospheric oxygen: the role of heterotrophic microbes. Aquat Microb Ecol 11:91-100

Smith SV, Hollibaugh JT (1996) Coastal metabolism and the oceanic organic carbon balance. Rev Geophys 31:75-89

Smith SV, Hollibaugh JT (1997) Annual cycle and interannual variability of ecosystem metabolism in a temperate climate embayment. Ecol Monogr 67:509-533

Werner FE, Viúdez A, Tintoré J (1993) An exploratory numerical study of the currents off the southern coast of Mallorca including the Cabrera Island complex. J Mar Syst 4:45-66

Williams PJLeB (1998) The balance of plankton respiration and photosynthesis in the open ocean. Nature 394:55-57

Williams PJLeB (2000) Net production, gross production and respiration: what are the interconnections and what controls what? In: Hanson RB, Ducklow HW, Field JG (eds) The changing ocean carbon cycle. International Geosphere-Biosphere Programme Book Series 5. Cambridge University Press, Cambridge

Williams PJLeB, Raine RCT, Bryan JR (1979) Agreement between the ${ }^{14} \mathrm{C}$ methods of measuring phytoplankton production: reassessment of the photosynthetic quotient. Oceanol Acta 2:411-416

Ziegler S, Benner R (1999) Dissolved organic carbon cycling in the water column of a subtropical seagrass meadow. Mar Ecol Prog Ser 188:51-62

Submitted: January 23, 2004; Accepted: July 16, 2004 Proofs received from author(s): October 6, 2004 